\title{
The craft of reference: the Welsh language and the division of labor in nineteenth century slate quarries
}

\author{
H. Paul Manning \\ Department of Anthropology, Bard College, New York, 12540, USA
}

In the latter part of the nineteenth century, the North Welsh slate-quarrier came to be so associated with the Welsh language that by 1893 a poet going by the bardic name of Glan Elsi felt able to connect the fate of the language with the fate of the slate industry [Owen (Glan Elsi), 1893, p. 112]:

Dearest old Welsh, if ever it dies, From the lips of a quarrier, I think, will come the final word.

If non-quarriers in Wales came to see the Welsh language and slate-quarrying to be intrinsically, indeed ethnically, linked (Merfyn Jones, 1986, 1992), this was so only because the quarriers themselves had earlier on articulated a linguistic ideology that seemed to make their linguistic Welshness an integral 'factor of production' that confirmed them in their role as workers. However, the linguistic ideology was not one which presented linguistically different groups being differentially recruited to an autonomously existing division of labor by virtue of ethno-linguistic distinction, a colonial regime of 'linguistic division of labor' (adapted from Hechter's 'cultural division of labor'; Hechter, 1975, 1976). Rather, importantly, the quarriers themselves preferred to view their linguistic differences from the owners as being partially constitutive of the division of labor itself, a factor of production, so that Welshness was part of the 'craft of reference' that enabled a Welsh worker to properly assess slate rock referentially (which had crucial importance in wage negotations, as I will show below), part of a Putnamian 'division of linguistic labor'. This paper seeks, by focussing in ethnographic detail on the speech genres that constituted the wage

E-mail address: hpm1@midway.uchicago.edu 
contract system of the quarriers, to show how the opposition between English capital and Welsh labor (a 'linguistic division of labor') could be ideologically re-valorized as implying an kind of equality and autonomy, in which Welsh was the language of slate rock in its natural form par excellence, and English the language of slate in its cultural form as finished commodities (a 'division of linguistic labor').

\section{Ideologies of language and the division of labor in nineteenth century Gwynedd}

The slate quarries of nineteenth century Caernarfonshire and Merionethshire (modern day Gwynedd) drew their labor exclusively from monoglot Welsh populations in the area. ${ }^{1}$ Slate quarrying towns like Ffestiniog and Bethesda routinely showed the highest percentages of Welsh speakers of any urban area in Wales in successive censuses. ${ }^{2}$ The populations of these towns were, moreover, increasingly self-conscious of their role as exemplary Welsh-speaking communities (Davies, 1980), ${ }^{3}$ just as they were aware that capital in the largest quarries was almost exclusively of English derivation, as were most of the large quarry owners themselves. The division between Labor and Capital in these quarries correlated to a virtually categorical linguistic opposition between Welsh quarriers and English owners, with the question of the proper linguistic and ethnic identity of managers a hotly disputed one throughout the period. Moreover, to this self-conscious linguistic divide there corresponded a broader cultural and political one: the stereotypical quarrier was Nonconformist, the owner Anglican; the quarrier a Liberal, the owner a Tory, and so on (Merfyn-Jones, 1982, 1988). In the quarries, then, ethno-linguistic identity and class position tended to reinforce one another, and became aligned in the ideology of the quarriers and the broader Welsh public alike. Such a situation, where pre-existing linguistic and cultural difference serves as a diacritic regulating recruitment to an autonomous system of social or economic differentiation, could be described as a 'linguistic division of labor', a variety of Hechter's 'cultural division

\footnotetext{
1 The data collected by Jones (1998) for population migrations in Merioneth and Caernarfonshire (the locations of the slate quarries) for the period from 1851-1911 show consistently that the bulk of the population in these shires hailed from within Wales, usually from adjacent shires. Thus, for Merioneth, anywhere from $91-97 \%$ of the population enumerated were born in Wales, as opposed to $2-7 \%$ from England; for Caernarfonshire $88-97 \%$ born in Wales, as opposed to 3-9\% from England.

2 The data collected in Jones (1998) makes it clear that the highest and most stable percentages of Welsh-speaking population were the quarrying districts, with the urban district of Ffestiniog in Merioneth showing $98 \%$ of the population able to speak Welsh in successive censuses (1901 and 1911), as compared to scores anywhere from $76 \%$ (Barmouth in 1911) to $93 \%$ (Mallwyd in 1901) for other urban districts in Merioneth, and scores from 91\% (Dolgellau in 1911) to 97\% (Deudraeth in 1901) for rural districts. Even more strikingly, for Caernarfonshire the urban shire of Bethesda scored $99 \%$ Welsh-speaking population in successive censuses (1901-1911), the other urban districts (and municipal boroughs) ranging from 70\% (Conwy in 1911, with Llandudno an outlier at 44\% in 1911) to 95\% (Yscynhaearn in 1911), and rural districts ranging from $81 \%$ (Conwy in 1911) to $98 \%$ (Gwyrfai in 1901 and 1911). This makes Bethesda the 'most Welsh' spot in Wales for two successive censuses.

${ }^{3}$ As one quarrier put it later: "Since every one who went to the quarry was a boy from a monoglot Welsh home, the Welshness of the quarriers can be attributed to that, and that's the reason that it is the quarrying shires that are the most Welsh in Wales." (Williams, 1942, p. 132)
} 
of labor', in which individuals are assigned 'to specific roles in the social structure on the basis of objective cultural distinctions' (Hechter, 1975, p. 39, 1976).

At the same time, Welsh stood as a linguistic metonym of the entire range of technical skills which the workers possessed and the owners did not, so that Welsh stood to English as Industry to Market, and both languages (and consequently speakers) had their proper sphere, a functional complementarity, a 'division of linguistic labor' (Putnam, 1975). This sense of functional complementarity is rooted, I would argue, in the productivist ideology of the workmen, which 'is a normative critique of nonproductive social groupings from the standpoint of those groupings that are "truly" productive; it makes 'productiveness' the criterion of social worth' (Postone, 1993, p.64). Such a critique of social relations from the perspective of productive labor involves a fairly sharp disjunction between two aspects of commodity production (on which see Marx, 1990, p.283ff; Postone, 1993, p. 325ff), namely the production of use-values (the 'labor process' of production) intrinsically associated with industry as opposed to the extrinsic logic of (exchange) value (the 'valorization process' of production) which was felt to belong to the market in which the products of industry were distributed (Postone, 1986, 1996). Since the labor process is conceived as a purely technical, fundamentally asocial, process, this ideology tends to naturalize the former labor process of production as a basis to emphasize and critique the fundamentally social and conventional (indeed 'artificial') nature of distribution. Thus productivist ideologies tend at the same time to ideologically naturalize the labor process even as they conventionalize the valorization process of production (for this distinction see Parmentier, 1994):

[B]ecause labor. . constitutes the relationship between humanity and nature, it serves as the standpoint from which social relations among people can be judged: Relations that are in harmony with labor and reflect its fundamental significance are considered socially 'natural'. The social critique from the standpoint of 'labor' is, therefore, a critique from a quasi-natural point of view, that of a social ontology. It is a critique of what is artificial in the name of the 'true' nature of society. (Postone, 1996, p.65)

The workers mapped these two complementary functional domains of commodity production (natural 'labor process' versus conventional 'valorization process') onto the linguistic division between Welsh and English, such that the labor process (which produces 'use values') requires particular Welsh skills embodied in a 'Welsh quarry language', while the valorization process (which produces '(exchange) values') was the functional sphere of English. This duality of perception of the relation of the quarriers and their language to the owners and their language, I would argue, is conditioned by the wage contract system under they worked, a form of 'formal subsumption of labor under capital' which, in the terms of the times, involved 'the elimination of the employer but not the capitalist' (Price, 1969 [1891], p. 156). That is, under formal subsumption, the labor process of production continues in a semiautonomous form, and the interactions between Labor and Capital take the form of purely economic relations of autonomous buyers and sellers of commodities, 
whereas under real subsumption, Capital stands to Labor in the political capacity of 'employer' to 'employee', and takes direct control of the labor process of production (Price, 1984; Marx, 1990, p. 1019ff; Postone, 1996, p. 283ff). Moreover, the very wage contract system seemed to confirm the separateness of the labor process and the valorization process of production, since these seemed to occur at different times and different places, and were associated with different personnel and ultimately, different ethnicities and languages.

The workers applied this functional opposition between Welsh and English to the speech genres that constituted the wage contract system, seeing here a 'division of linguistic labor' in which Welsh was the proper language for the assessment of slate rock in its 'natural' form, and English the proper language for the appraisal of slock in its 'cultural' form as finished commodity. Their productivist ideology naturalized the relationship of the Welsh language to the perceivedly natural labor process of production, even as it pari passu confirmed English as the sphere of all that was extrinsic to production and therefore social and conventional. This naturalization of Welsh as reflecting a 'natural' world of production allowed them to critique managerial interventions in the sphere of production as being not only culturally alien but indeed unnatural and artificial. Even so, in so doing they naturalized the 'linguistic division of labor', a point to which I now turn.

\section{The linguistic division of labor}

The slate quarriers would often present their relation to the slate rock in naturalized terms, often with a certain amount of dry irony, in which they would invert the existing 'linguistic division of labor.' In the quarries, English owners would usually appoint English managers, and deny such promotions to Welsh-speakers (a linguistic division of labor), thus making English ethno-linguistic identity a qualification for management. The Welsh ideology would ironically reverse this association, taking Welsh ruefully as a positive qualification to work the rocks, because 'the rocks do not understand English', as in this early song from the 1840s (Merfyn Jones, 1982, p. 78):

If officials are needed/ They are at once sent for from afar,

Either Irishman, English or Scots/ Are in jobs almost everywhere

In works here in Wales/ Englishmen can be seen interfering/

You must get Welshmen to break the stone,

For the rock does not understand English

This inversion is crucial, for what seems initially to be a straightforward case of invidious distinction based on language, by which qualified Welsh workers must defer to unqualified English owners and managers (a linguistic division of labor), becomes instead naturalized so as to make a positive argument for the naturalized autonomy of the workforce from extrinsic and 'artificial' supervision. English interlopers came to be seen alien not only to the cultural order of Wales, but also the 
natural order (if only metaphorically), just as the 'English method of working quarries' was alien and inefficient compared to the 'Welsh Way of working quarries', even as (or because?) it tried to subordinate the natural rhythm of unsupervised Welsh labor to an artificial regime of time management:

Welsh is what everyone, with but a few exceptions, speaks in Ffestiniog. Welsh is the language of the land and the quarries, and Welsh is what the rocks, and the sheep who browse our slopes, have learned. The English thought that there was a way to work our quarries. . .in English, and do twice as much of everything as used to get done in the same amount of time. (Treborfab, 1890, p. 5)

Many slate quarriers apparently naturalized their skill as an innate or inborn ability proper to the Welsh, as a slate quarrier of the period noted:

Some of the Welsh would argue, particularly some of the quarriers, that there is a particular aptitude (cyfaddasrwydd), or innate genius, in the Welsh [people], more than in any other nation, to work slate, just as it is said that no one but the Welsh can play the three-rowed harp. (Peris, 1896 [1875]. p. 273)

Such a view had logical consequences for the quarriers' criticism of the 'division of linguistic labor' in management. The term 'quarry-bastardism' was applied to hiring non-quarriers, and therefore non-Welsh, as quarry managers, which went, in effect, against the natural order (Carwr Cyfiawnder, 1875, p. 13; Roberts, 1875, p. 13);

The worker...is the highest in understanding quarrying; he is the only one learned; he is able to understand the language of the rock. The slate rocks here have a language, but the worker out of everyone is the interpreter. An old Welshman here some time back would say that "in Welsh a quarry will work; it won't work in English," said he. There is truth in that old saying, although the language of those rocks is not Welsh; yet, it is the Welsh who have been up to now most successful in learning it. (Twll-Dwndwr, 1874, p. 13)

By positively valorizing and naturalizing the very ethno-linguistic diacritic (Welsh speaking versus English speaking) that tended to exclude them from management as constitutive of their skill (and concomitant claims for craft autonomy), the Welsh workers were doing more than simply confirming their subordinate status in production. Rather, they were making a strong argument (in productivist terms) for the technical autonomy of industrial production from the interference of owners and managers. Thus, they were arguing in defense of their existing contract system (a form of 'formal subordination of labor to capital') which guaranteed the autonomy of the labor process, as against the continued attempts of owners and managers to insert themselves into the labor process ('real subordination of labor to capital'). By arguing that each language (and its associated speakers) had distinct spheres of referential adequacy, they were making an argument for a 'division of linguistic labor', to which I will now turn. 


\section{The division of linguistic labor}

When quarriers spoke of the 'English method of running a quarry', they were referring above all to attacks on the traditional system of craft control, the 'Welsh method of working a quarry'. There were a number of dimensions to this opposition, yet all revolved in one way or another around the quarriers' practical knowledge of quarrying, their skill, which they associated with their language. The 'Welshness' of their skill was indexed in its linguistic dimension. They took their technical terminology, the so-called 'Welsh quarry language', as congealed linguistic evidence of this collective skill. The craft of slate quarrying, indeed, the fact that it was a craft, was reflected and emblematized in the craft of reference, and the terminology employed in reference to slate, which was felt to be essentially untranslatable. As in many other crafts, the difficulty of the 'craft' of slate-quarrying was indexed iconically both in the difficulty and profusion of its terminology, as well as in the 'craft' of reference, the difficult skill of deploying these terms referentially. In short, slate-quarrying terms were part of 'division of linguistic labor' that was itself a product of the broader division of labor. Putnam, writing in the late-twentieth century after a progressive separation of hand and brain, word and deed, assumes that such a linguistic division of labor is mostly a matter of scientific experts, and not craftworkers.

[T]here is a division of linguistic labor. We could hard use such words as 'elm' and 'aluminum' if no one possessed a way of recognizing elm trees and aluminum metal; but not everyone to whom the distinction is important has to be able to make the distinction... The foregoing facts are just examples of mundane divsion of labor (in a wide sense). But they engender a division of linguistic labor: everyone to whom gold is important for any reason has to acquire the word 'gold'; but he does not have to acquire the method of recognizing if something is or is not gold. He can rely on a special subclass of speakers...This division of linguistic labor rests upon and presupposes the division of nonlinguistic labor, of course...And some words do not exhibit any division of linguistic labor: 'chair', for example. But with the increase of division of labor in the society and the rise of science, more and more words begin to exhibit this kind of division of labor. (Putnam, 1975, pp. 227-228)

Here, I will use the Putnamian concept of division of labor in referential practices in a loose sense as suggested by Irvine (1996, p. 271), so as to draw out the useful parallels between the [scientifically] authoritative utterances of appraisers about natural kinds like 'gold' and the utterances of quarriers rendered authoritative by craft knowledge about natural kinds of slate bearing rock, both of which are implicated in a wider division of labor in different ways.

This kind of process applies not just to gold, but to any exchangeable item invested with social value, where only an 'expert' can tell if it 'really' is what it purports to be...Just what is invested with what sort of value, and which 
persons get into the position to speak authoritatively about the value, must vary from one society to another. What this process suggests, however, is that perhaps any system of prestations and counter-prestations-that is, an economy (in a broad sense) - will necessarily include authoritative statements as part of the exchange system. (Irvine, 1996, p. 271)

For the quarriers, the most distinctive and most jealously guarded aspect of their position as skilled workers was their contract system. The kind of contract system the workmen worked under was called the 'bargain system' (Merfyn Jones, 1982, p.83ff), a species of 'internal contract' system (Littler, 1982) with wages based on piecework, contracted out by small crews of 'partners'. This system gave them the appearance of working as individual crews of simple commodity producers who 'sold' their product to the owner of the quarry. The term 'bargain' represented both the contract struck and the actual site in the quarry. Such a system can have the appearence of eliminating the political subordination of employee to employer while retaining the economic (formal) subordination based on property ownership, hence 'formal subsumption of labor by capital' as opposed to 'real subsumption of labor by capital'. Formal subsumption, again, involves a formal equality and autonomy between employer and employee, so that the employee is only economically (formally) subordinated to his employer, but the control of the actual labor process remains essentially unchanged, that is, there is no political dimension in which the employer intervenes in the labor process, as there is in real subsumption. Relations between employer and employee are entirely mediated by the wage contract, and their relations take on the appearance of egalitarian relations of commodity exchange. Moreover, in such a system, the labor process of production appears to be entirely autonomous from the extrinsic logic of the valorization process, so that the former is the proper sphere of the workers, and the latter the proper sphere of the owners. Production appears to be divided into a purely technical and natural labor process, followed by a purely social and conventional valorization process.

\section{Speech genres of 'bargaining': 'setting' and 'settling'}

The contract system in the quarries involved two occasions where authoritative utterances about value constituted the exchange (Fig. 1). Both of these appeared to be constative speech acts of reference (and, indeed, their authoritativeness depended crucially on their status as truthful acts of 'correct reference'), but both were consequential performative acts (affecting payment more or less directly).

The linguistic division within production between Welsh and English was also associated with, and projected onto, the very speech genres (Voloshinov, 1973, p.20) that constituted the 'bargain system' itself, so that there arose at least in quarriers' ideology a 'division of linguistic labor' that gave control of Welsh an economic role. The workers in a quarry normally had direct contact with representatives of the owner only on two days in a given month, setting day, where the bargain would be 
set, and settling day, where the slates would change hands (Fig. 1; Coedwigwr, 1875, p. 14).

These two days were associated with two very different speech genres, both involving assessment of slate, once in its natural form (craig 'rock') as raw material during setting, and once in its cultural form as commodity (cerrig 'rocks') during settling. On 'settling day' (Sadwrn setlo) the 'selling' of finished slates to the owner occurred. Here clearly a division of linguistic labor would be least in evidence, because all would wish to be able to agree on the name (if not the quality, see above) of the commodity that was changing hands, and therefore, its 'making price'. At this time the skill of the work is displayed in congealed form in the slate itself. The speech situation is one of relative symmetry, in that both parties agree on the proper referential application of terminology for the finished slates. There is little 'division of linguistic labor' in evidence, aside from, perhaps some disagreements as to the quality of the slates. This genre could be said to be relatively presupposing in its form of indexicality (Silverstein, 1976), since most of the variables at stake (poundage and therefore making price) have already been established in the setting.

The day after 'settling' came 'setting day' (diwrnod gosod), also called 'the day of the guess' (diwrnod y ges; Twll-Dwndwr, 1874, p. 14). In contrast to the relative symmetry of 'settling', in 'setting' there was a possibility for a 'division of linguistic labor' that substantially favored the quarriers. Moreover the speech genre itself was relatively creative (Silverstein, 1976): the bargain setting (gosod) involved acts of authoritative appraisal of the rock of the 'bargain' (during the 'letting'), during which speech act the relative expertise of workers and managers in appraisal of the rock (reflected linguistically) had consequences for wages (resulting in bonuses, called poundage or 'bounty' (mownti) added to the 'making price' of the slates). At the beginning of a month, a bargain (a swatch of rock face in the quarry) was 'let' to

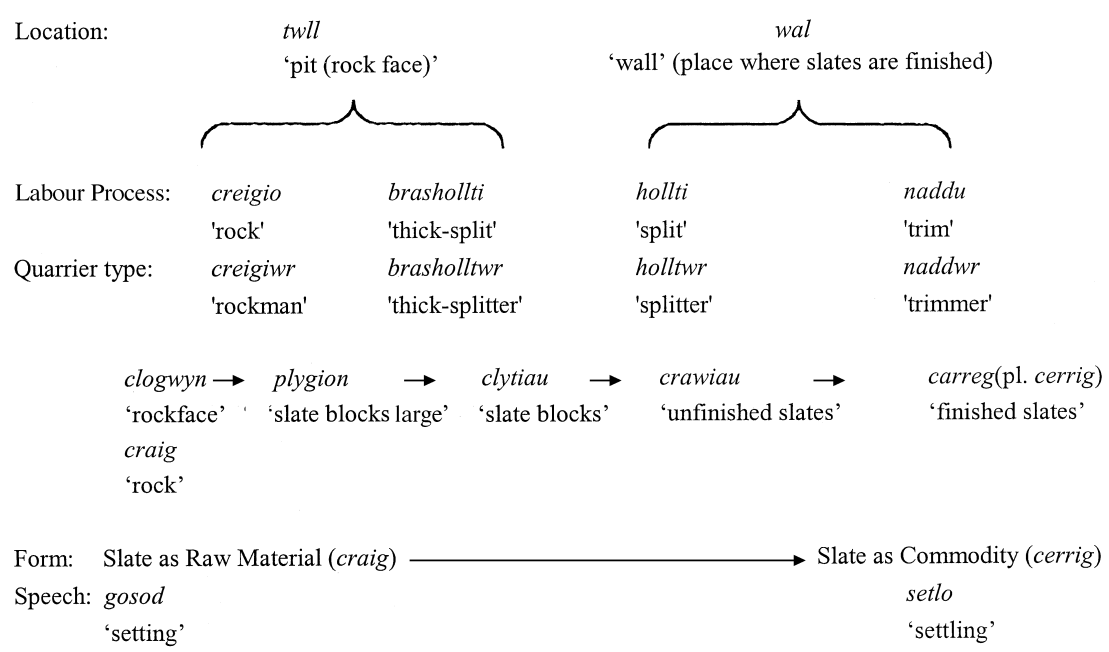

Fig. 1. Diagram of the labor process of slate quarrying (following Peris, 1896 [1875]). 
a crew to work for a given month, and on the basis of the quality of the rock, to the 'making price' would be added wage bonus, called the 'poundage': the worse the rock, the higher the poundage. Note that, in contrast to Putnam's vision of a division of linguistic labor as part of a 'structured cooperation' (Putnam, 1975, p. 228), setting was felt to be an essentially non-cooperative speech genre, in sharp contrast to settling:

It was an old custom amongst the rockmen [creigwyr] to point out every defect and disadvantage that pertained to the rockface [clogwyn] on setting day, and hide as much as possible every advantage and excellence. 'Boy, it's a fine bed [of slate],' said the steward. 'What will it make?' 'About three yards [of finished slates]' said Sion Dafydd. 'Well, what's your price?' asked the steward. There was a fervid argument about the price. Sion Dafydd went on about the mess that was on the face of the bed first of all, how many 'feet' [traed, a kind of defect in the slate] and 'backs' [cefnau, another defect in the slate] and 'curl' [sic, crych, another defect in the slate] he had seen (Lloyd, 1926, p. 39)

Even within this speech genre of 'setting' (gosod), there were two variations that once again recursively echo the opposition between the 'English method' and the 'Welsh method'. There were thus two basic strategies involved in 'setting', one which favored management, the other which favored the quarriers.

We have seem many methods of setting ( gosod), of which I can note setting by the bill, and setting by the rockface [clogwyn]. The old system of setting by the bill killed the energy of the workers as if with a single blow; while setting by looking at the rockface, and losing sight of the bill that was made the previous month, brings out all of the exertions of man to do his best (Peris, 1896 [1875], p. 211).

The former 'English method' of setting ['setting according to the bill' (gosod wrth $y$ bil)], involved changing the poundage on a subsequent month on the basis of the bill "bill"' (that is, the wages of the crew calculated on the basis of the number of finished slates and 'making price' as adjusted by poundage) of the previous month, lowering the former as the latter increased. This was felt to penalize worker productivity, but it did not require any special ability to appraise slate rock (and hence was appropriate to an unskilled English manager). The proper, and just method, according to the quarriers, was 'setting according to the rock[face]' (gosod wrth $y$ clogwyn), which implied taking into account the quality of the rockface to adjust the poundage. In some sense, only this method of 'setting' could be called 'bargaining' (bargeinio). Worker accounts treat this speech act as being in effect a kind of special oratory, 'Every crew had its speaker to argue its cause, and many of them were eloquent orators, as good as any attorney! The rest [of the crew] stood following the course of the bargaining (bargeinio) and releasing an occasional sigh or 'amen' according to the call' (E. Jones, 1964, p. 21). This required considerable knowledge of the quality of slate rock, and the resulting inference about the proper source of management is inevitable: 
It, therefore, follows that every manager, without exception, should be a practical quarryman; if not, the quarrymen, on every "letting day," are perfectly sure to take advantages of his ignorance to improve their own position. Strictly speaking, it is not right to do this; but who, and where are the immaculates that will not, if they can? They will say that the rock, the "bargain," is ten times worse than it really is; that is has no "foot-joints" here, too many there, too "hard" to split here, and too "brittle" there. The inexperienced manager cannot contradict them. (Richards, 1876, pp. 18-19)

In spite of the dangers of setting 'according to the rock', setting 'according to the bill' was considered to be an essential perversion of the bargain system, part and parcel of 'quarry-bastardism', because it subordinated the perceivedly autonomous technical logic of production (conceived of as a purely technical and asocial natural process of the production of use-values) to an 'alien' and extrinsic (unnatural and conventional) logic of pricing. While 'setting' and 'settling' are kept apart, then the natural logic of the labor process and the conventional logic of the valorization process are kept in their separate and complementary spheres. But, after all, 'setting day' for the next quarry month comes immediately after 'settling day' for the last month, and thus part of the 'English way of working a quarry' is to conflate the two (a recursion of the logic of 'settling' within the genre of 'setting'), subordinating the technical logic of production to the social logic of valorization. Moreover, this 'old' system of bargain setting (setting by the bill) is also associated rather directly with English-speaking management. One observer of the English method connects the two series, producing a linguistic image of a pidgin-Welshspeaking English manager as foreign to the natural order of slate quarrying, who uses the method of 'setting by the bill' because he does not understand the Welsh rocks:

I understood while watching the supervisor that he was a stranger, a stranger to the Welsh language, and a stranger to the language of the rocks (creigiau), although the made faces like one who understood, and pretended to pay careful attention and listen intently as if in conversation with the rock, and pretended to translate what was said to the workers... [At one such quarry the writer visited] there was a crew working a bargen... and one of this brotherhood was the supervisor. The danger of the crew was to make too many slates... and because their bargen was a very good one, it would be a calamity for them to go higher than the supervisor would allow. But no matter how much their care, one month the bill went higher than they had thought, and they knew what would be the consequence... [W] [Wen the day of the call came, it began to thunder on them: 'Well Robin, you make too much of bill, Me pull poundage away every penny' (Twll-Dwndwr, 1874, p. 13).

The alternative, in the 'Welsh method', is to keep these two speech genres (setting and settling) separate and autonomous, so that the setting occurs according to 'natural' rather than 'social' rules. 


\section{Setting by the rock: the craft of reference}

If there is to be 'setting according to the rock', the speech situation requires that the two parties, the bargain crew and setting steward, share some quarrying terms such as crych 'curl', and an associated language, such as Welsh, and that both parties know at least part of the intension of words like crych, that, for example, slate rock with crychs in it will not yield good slates. Indeed, whatever the specific sort of crych and associated properties, the shared intension of all crychau is that they render the slate rock unworkable (the majority of the crychau are faults in the regular course or grain of the slate) or the finished slates worthless (the crych $d u$ is simply an unsightly discoloration Fig. 2; R. E. Jones, 1964, p. 110).

Thus, crucially both parties must recognize that a bargain with crychau 'means' increased poundage (to compensate for the low yield and difficulty of working of the slates). However, only one party (the crew) knows the 'necessary and sufficient conditions for membership in the extension, ways of recognizing if something is in the extension' (hence, particularly, practical referential command of the more specific varieties of crych; Putnam, 1975, ibid.). Thus, taxonomically, both sides must know generally what a crych is denotationally (a general class of defect all of which render slates worthless, a matter of general concern), but only one party must have the referential ability to diagnose specific varieties of crych (because the nature of the faults that make slates worthless or unworkable are a matter of practical concern only for the craft worker). There is thus an asymmetry in linguistic production, the ability to authoritatively extend the word crych referentially, to say whether this or that bargain has crychs (of a specific variety) in it, with crucial economic consequences (a true 'profit of distinction'; Bourdieu, 1994, p. 18). The division of linguistic labor in this speech genre becomes a division between passive recognition, the intension, without controlling the active application, the extension, of such terms, an asymmetry of evaluation (recognition) and production of the sort constitutive of 'distinction' and symbolic domination (Bourdieu, 1994). Here, however, it is 'craft knowledge' that makes the 'distinction'.

The quarriers draw attention to asymmetry of practical control of Welsh slate quarrying terminology as a central advantage they have over 'English' management during setting, partially as part of their over-all project to critique this managerial system as being as bad for the owner as it is for the worker. English managers, quite

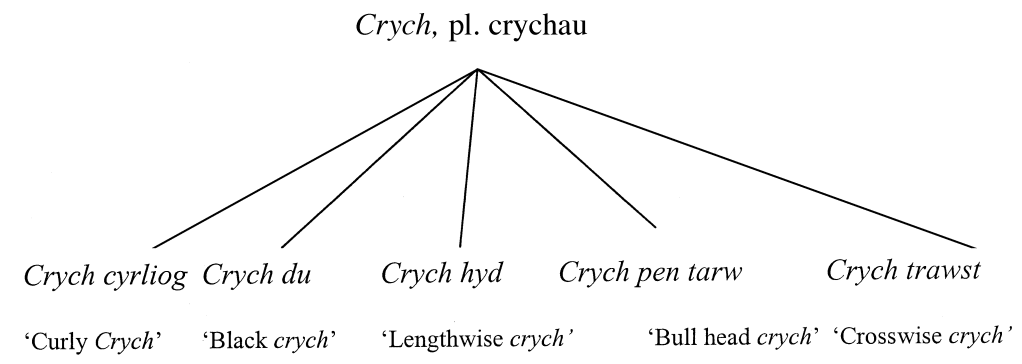

Fig. 2. Taxonomy of types of crych (a defect in the slate). 
simply were incompetent linguistically to perform the speech genre of 'setting' (though they were in their proper element with 'settling'), either because they would set according to unnatural criteria (the 'English method' of 'setting according to the bill'), or because they would be taken advantage of by workers because of their lack of referential and craft knowledge while 'setting according to the rock[face]'. Clearly, above all else it was the lexicon of slate quarrying that the workers found 'good to think', as they displaced these asymmetries of the craft of reference onto the terms which display such asymmetries of application and recognition. Here too, as I will show, the workers' naturalized productivist ideology was given further expression in the way they saw the lexicon itself as being etymologically divided between English and Welsh, so that terminology associated with craft production and 'setting' was Welsh, and terminology associated with 'settling' was English.

\section{Conclusions: divisions of labor and lexicon and isoglosses of production}

We have seen the way that the quarrier's ideology seeks to transform or critique existing 'colonial' modes of interaction which subordinated Welsh workers to English owners and managers into complementary and autonomous modes of interaction, in effect, transforming a 'linguistic division of labor' into a 'division of linguistic labor'. Throughout I have attempted to ground this ideological position in the 'productivist' ideology of the workers that rhetorically naturalized the existing alignment of Welshness and slate-quarrying, so that the workers could claim that their industrial activity (which, after all, presented itself as a purely technical, natural interaction with nature) should be autonomous from and complementary to the ultimately extrinsic life of the rock in its form as commodity (dictated by the perceivedly purely social, conventional interactions of the market). I have also tried to show (following the meta-semiotic spirit of the times and the quarriers themselves in grounding their moral life in their material life) that this productivist ideology itself is in some sense conditioned by the nature of their wage contract, which in itself seemed to separate use-value from (exchange-)value, industry from market, labor from capital, rock in natural (raw material) and social (commodity) form, as being separate, autonomous and complementary aspects of a whole.

These productivist oppositions between Capital and Labor have been shown to be refracted recursively linguistically on a number of levels (images of speakers and speech, genres of interaction, and so on), but it is appropriate to conclude that this opposition between English and Welsh is recursively projected in the quarriers' ideology onto the Welsh language and the quarrier's terminology itself. In effect, the very lexicon of quarrying reproduces the opposition of Labor and Capital as an isoglossic opposition between Welsh and English etyma.

As is common in metalinguistic awareness (Woolard, 1998, p. 14), the workers themselves tended to focus on the terminology as if, indeed, the words were their skill incarnate. The slate quarriers appeared to see the topology of the division of labor reflected iconically in the topology of the lexicon, as they attributed special 
vocabularies to others involved in the quarry's division of labor. For example, the unskilled workers in the quarry tended to come from agrarian backgrounds in nearby rural districts. These 'farmer-quarriers' could be easily recognized, according to one author, himself a 'true' quarrier, partially 'because there would be cow dung and slate dust mixed on their shoes' (E. Jones, 1964, p. 80), but also because of their incomprehensible pastoral vocabulary. The sheep herding terminology that speckled their conversation indexed their mixed identity 'quarriers' and 'farmers' rather than true quarriers just as surely as the mixture of quarry dust and cow dung on their boots (E. Jones, 1964, p.80). In a similarly ethnicized partitition of the lexicon, quarriers felt that the names of the sizes for the finished slates, in contrast to the rest of the quarrying vocabulary, were essentially 'English' in origin. Indeed, stories were in circulation as to their origin, and all of these stories attribute the name of the finished commodity to a specific English agent or slate owner, or simply to the English in general. An early commentator invented a just-so story in which the names for finished slates arise from a preceding state of Babel-like confusion of confused and confusing workers' terminology, which, interestingly attributed the new terminology to a source which is generically 'Non-Welsh':

It was necessary to get some names for the finished slates that everyone could understand and remember; and the names that were given to them prove at once that it was not a Welshman who was their godfather [tad bedydd]. They are called Queens, Princesses, Duchesses, Countesses, Ladies, Doubles, Singles, Puts. (Jones, 1886, p. 137)

While this account simply attributes these names to an anonymous non-Welsh source, other accounts are more specific. Importantly, in these other baptismal histories, these names for finished slates, far from being rooted in the collective craft knowledge of the slate quarriers, are in each case attributed to a singular 'foreign' source. For example, certain slates called docers are attributed to a slate merchant named 'Mr. Docker' (Jones, 1894; R.E. Jones, 1964, p. 377), and other slates called puts are named after a William Pitt, another slate agent (R.E. Jones, 1964, p. 377). The 'court sizes' are variously attributed either to Lord Penrhyn, at the advice of his lady (Jones, 1894), or to a previous owner of the same quarry and affinal relative, General Hugh Warburton (Lindsay, 1974) or partially to one or another of these individuals (Jones, 1907 [1863]; R.E. Jones, 1964, pp. 376-367). What is curious that the folk ideology attribute these terms for finished slates, to English sources, while the rest of the slate quarrying vocabulary was an anonymous and collective in origin as it was Welsh.

Why these terms? In the internal contract system of the 'bargain', the bargain crew confronts the owner or his agents in the quarry at two times in a given month of a bargain. During the remaining time, when the crew is actually working the bargain, there is virtually no interaction. At the bargain setting, the 'making price' of the slates is decided ideally on the basis of purely industrial and technical considerations. The second time the slate makers confront the owner is at the end of the quarry month, when they 'sell' their slates to the owner, and the crew are paid as if 
owners of particular commodities, slates. With formal, as opposed to real, subordination of labor to capital, the labor process of production (the 'making' of the slates) appears to be sequentially followed by an extrinsic valorization process (the 'sale' of the slates), as if these two moments of production are separated spatially and temporally, standing as 'industry' does to the 'market'. Following this logic, Welsh, the technical terminology of the labor process and its 'raw material', 'industry', confronts English as the names of the commodities which belong to the valorization process, the 'market'. Welsh mediates human interaction with nature in production just as English mediates human interaction in exchange. In the eyes of the quarriers, the rock (craig) speaks Welsh, but finished slates (cerrig) speak English.

\section{Acknowledgements}

The material on which this paper is based was collected in Wales during the summer of 1999 with the aid of a Reed College Faculty Research Grant. I wish above all to thank Dylan Morgan and his family for their patience and hospitality, without which this paper could not have been completed. I would like to thank Talbot Taylor, Michael Silverstein, Chris Kirby, Devin Pendas, my colleagues and students at Reed College and Bard College for their comments on various drafts of this paper. Errors are my own.

\section{References}

Bourdieu, P., 1994. Language and Symbolic Power. Harvard University Press, Cambridge, MA.

Carwr Cyfiawnder, 1875. Chwarelydd a goruwchwiliwr. [Quarries and the supervisor]. Y Baner ac Amserau Cymru May 26, 13.

Coedwigwr, 1875. Chwarelau Dinorwic. [The Dinorwic quarries]. Baner ac Amserau Cymru July 7, 14.

Davies, G., 1980. Community and social structure in Bethesda. Transactions of the Caernarvonshire Historical Society 41 (12), 107-127.

Hechter, M., 1975. Internal Colonialism. University of California Press, Berkeley.

Hechter, M., 1976. Ethnicity and industrialization: on the proliferation of the cultural division of labor. Ethnicity 3, 214-224.

Irvine, J., 1996. When talk isn’t cheap: language and political economy. In: Brenneis, D., Macauley, R.K. (Eds.), The Matrix of Language. Westview Press, Boulder, CO, pp. 258-283.

Jenkins, G., 1998. Language and Community in the Nineteenth Century. University of Wales Press, Cardiff.

Jones, D., 1998. Statistical Evidence Relating to the Welsh Language 1801-1911. University of Wales Press, Cardiff.

Jones, E., 1964. Canrif y Chwarelwr. [The Century of the Quarrier]. Gwasg Gee, Caernarfon.

Jones, H.M., 1886. Y chwarelwyr. [The quarrier]. Y Geninen 1886, 137.

Jones, R.E., 1964. Casgliad o dermau chwarel [A collection of quarry terms]. Bulletin of the Board of Celtic Studies 20 (4), 373-388.

Jones, R. (Bethesda).,1907 [1863]. Y Chwarel Fawr. [The Big Quarry]. Y Gwyliwr, March 5, $1907,7$.

Jones, J.O., 1894. Quarrying at Bethesda. Wales 1, 162-168.

Lindsay, J., 1974. A History of the North Wales Slate Industry. David and Charles, Newton Abbot.

Littler, C.R., 1982. Deskilling and changing structures of control. In: Wood, S. (Ed.), The Degradation of Work? Skill, Deskilling and the Labour Process. Hutchinson, London, pp. 122-145. 
Lloyd, H., 1926. Hunangofiant Rybelwr. [The Autobiography of a Rubbler]. Swyddfa'r 'Dinesydd', Caernarfon.

Marx, K., 1990. Capital, Volume 1. Penguin, London Translated by Ben Fowkes.

Merfyn Jones, R., 1982. The North Wales Quarrymen 1874-1922. University of Wales Press, Cardiff.

Merfyn Jones, R., 1986. Y Chwarelwr a'i gymdeithas yn y bedwaredd ganrif ar bymtheg. [The quarrier and his community in the Nineteenth Century] In: Cof Cenedl: Ysgrifau ar Hanes Gymru. Gomer, Llandysul, pp. 127-155.

Merfyn Jones, R., 1988. Ethnicity and class in the Penrhyn lock-outs, 1896-7: 1900-3. In: Van Voss, L.H., Diederiks, H. (Eds.), Industrial Conflict: Papers Presented to the Fourth British-Dutch Conference on Labour History. Stichting beheer HSG, Amsterdam, pp. 41-48.

Merfyn Jones, R., 1992. Beyond identity The reconstruction of the Welsh? Journal of British Studies 31, 330-357.

Owen, J. (Glan Elsi), 1893. 'Y Chwarelwr' [The Quarrier]. Cymru 5, 112.

Parmentier, R., 1994. Signs in Society: Studies in Semiotic Anthropology. Indiana University Press, Bloomington.

Peris, D., 1896 [1875]. Chwarelyddiaeth [Quarrying]. Winning Essay, Eisteddfod Bethesda, 1875. Y Geninen $14,273-4,52-4$.

Postone, M., 1986. Anti-semitism and national socialism. In: Rabinbach, A., Zipes, J. (Eds.), Germans and Jews since the Holocaust. Holmes and Meier, New York, pp. 302-314.

Postone, M., 1996. Time, Labor, and Social Domination: A Reinterpretation of Marx's Critical Theory. Cambridge University Press, Cambridge.

Price, L.L., 1969 [1891]. 'West Barbary'; or notes on the system of work and wages in the Cornish mines. In: Burt, R. (Ed.), Cornish Mining: Essays in the Organisation of Cornish Mines and the Cornish Mining Economy, Augustus Kelley, New York, pp.121-206.

Price, R., 1984. Structures of subordination in nineteenth century British industry. In: Thane, P. et al. (Eds.), The Power of the Past: Essays for Eric Hobsbawm, Cambridge University Press, Cambridge, pp. $119-142$.

Putnam, H., 1975. The meaning of 'meaning'. In: Mind, Language and Reality: Philosophical Papers 2, Cambridge University Press, Cambridge, pp. 215-271.

Richards, M., 1876. Slate Quarrying and How to Make It Profitable. Evan Williams, Bangor.

Roberts, H., 1875. Chwarel Bryn yr Egwlys. [Bryn yr Eglwys quarry]. Baner ac Amserau Cymru June 2, 13.

Silverstein, M., 1976. Shifters, linguistic categories, and cultural description. In: Basso, K., Selby, H. (Eds.), Meaning in Anthropology. University of New Mexico Press, Albuquerque, pp. 11-55.

Treborfab, 1890. Siarad y Tren. [Talking [on] the Train]. Baner ac Amserau Cymru August 13, 5.

Twll-Dwndwr, 1874. Pa Fodd yr Aeth Bethesda Fel y Mae? [How did Bethesda get to be the way it is?]. Baner ac Amserau Cymru October 28, 1874,14; December 2, 1874, 13.

Williams, J., 1942. Atgofion chwarelwr. [Recollections of a quarrier]. Y Llenor Winter, 129-135.

Woolard, K., 1998. Introduction: Language ideology as a field of inquiry. In: Schieffelin, B., Woolard, K., Kroskrity, P. (Eds.), Language Ideologies: Practice and Theory. Oxford University Press, Oxford, pp. 3-47. 